\title{
POPULATION DYNAMICS OF SOME PESTS INFESTING NILI CUCUMBER PLANTATIONS IN RELATION TO CERTAIN ECOLOGICAL FACTORS
}

\author{
EI-LAKWAH, F.A. ${ }^{1}$, HORIA A. ABD-EI WAHAB ${ }^{2}$, M. M. KATTAB ${ }^{1}$, M. M. AZAB ${ }^{1}$ \\ AND MAHA S. EI-GHANAM ${ }^{2}$
}

1. Plant Protection. Dept. Fac. Agric. Moshtohor,Banha univ..

2. Plant Protection Research Institute Dokki- Giza, Egyp

(Manuscript received 18 October 2010 )

\begin{abstract}
Field experiments were conducted in Qalyubia governorate during two successive seasons 2007 and 2008 to study the population dynamics of some pests infesting Nili cucumber plantations namely Empousca decipiens (Paoli), Aphis gossypii (Glover), Bemisia tabaci (Genn) on two cucumber cultivars. Also the effect of certain weather factors (daily mean temperature, daily mean R.H.) and plant age were studied on the population dynamics of the various pests. The results revealed clearly no significant differences in the susceptibilities of the two cucumber cultivars (Hageen eshrak and Amira) to infestation with the above mentioned pests of cucumber plants during the two seasons. The weather factors (mean Temp. and plant age) had significant effect on the population dynamics of E. decipiens, A. gossypii and $B$. tabaci for the two cultivars. On the other hand the relative humidity had shown no significant effect on population dynamics of the three pests during the two seasons of 2007 and 2008 on the two cultivars. The percentage of variance was $92.7 \& 84.5 \%$ and 98.6 \& $94.2 \%$ for the two cucumber cultivars, during the two seasons, respectively. This means that the weather factors and plant age are responsible for about 92.7 in the variability of the populations of the observed pests on Hageen eshrak and $84.5 \%$ for Amira during 2007. The corresponding values during 2008 were 98.6 and $94.2 \%$ for the two cultivars, respectively.
\end{abstract}

\section{INTRODUCTION}

Cucumber, Cucumis sativus (Cucurbitaceae) is one of the most important cucurbitaceous vegetable cultivated in Egypt in both the open field and under plastic houses. Its cultivated area was increased during the last years especially in new reclaimed land for local consumption and exportation. Throughout the growing season, cucumber plants are liable to infestation by many phytophagous pests such as the aphids, Aphis gossypii (Glover.) and the tomato whitefly, Bemisia tabaci (Genn.), which considered the most common and important insect pests of cucumber plants. In case of heavy infestation, these pests are causing serious damage to plants, leading to great reduction in the yield (Hanafy 2004). Also they produce sticky honeydew, which cause damage 
to the crop (Perkins 1983 and 1987) and (Lenteren Van and Noldus, 1984). The whiteflies are minute, usually inconspicuous, and many are extremely injurious. They are efficient vectors of plant viruses (Bock et al., 1974). Aphids play an important role as a vector of plant viruses and produce honeydew Kasperovich (2002). Therefore, the purpose of this work was to study the effect of plant age and certain weather factors on the population dynamics of some pests infesting Nili cucumber plantations.

\section{MATERIALS AND METHODS}

The experiments were conducted at the experimental station of Sindyon, Qalyubia Governorate on two successive Nili cultivations during 2007 and 2008. An area of around $1 / 4$ feddan was sown with cucumber seeds (Cucumis sativus.) varieties (Hageen eshrak and Amira) 'on $15^{\text {th }}$ and $5^{\text {th }}$ of September during 2007 and 2008, respectively. Seeds were sown in rows at the rate of 8 rows $/ 2$ poles, the distance between the hills was about $30 \mathrm{~cm}^{2}$ apart on one side of the ridge. Normal agricultural practices were followed except for keeping, the whole area free from any pesticides treatment. Sampling started after about two weeks from planting and continued to the harvesting time. Weekly direct count of the whitefly, Bemisia tabaci (Genn.) adults was done cucumber (10 leaves/ replicate) chosen randomly from the plants early in the morning before the whitefly adults tend to be more active, (Gameel, 1973).After the direct count of adults, the samples were picked out and each put in a paper bag. Bags were transferred to the Laboratory for examination on the same day with the aid of a stereomicroscope. Samples were randomly taken from the infested plants in case of the cotton aphid Aphis gossypii Glover (Hemiptera-Homoptera-Aphididae) (Nymphs and adults), Empousca decipiens (Paoli) (Hemiptera-Homoptera-Jassidae) (adults) and the white fly, Bemisia tabaci (Genn.) (Hemiptera - Homoptera - Aleyrodidae) immature stages (larvae and pupae).Counts was done at weekly interval until the end of the season.

The records of meteorological data, the daily mean of minimum, maximum temperature and daily mean relative humidity, were obtained from the meteorological records of Central Laboratory for Agriculture Climate, Agriculture Research Center at Dokki, (preventative Shebien El-Qanater).The daily records of these factors were recalculated to get the daily averages within one week before the sampling date.

\section{Statistical analysis}

To investigate effects of plant age, climatic factors on the population dynamics of the insects, simple correlation and partial regression were carried out using a computer 
software package, " Costat" a product of Cohort software In C., Barkeley, California, U.S.A.

\section{RESULTS AND DISCUSSION}

Population dynamic, of Empousca decipiens (Paoli) Aphis gossypii Glover and Bemisia tabaci (Genn.) were studied on two cucumber cultivars in nili plantation. Also susceptibility of the two cucumber cultivars to the infestation by the three aforementioned insects in the two successive seasons 2007 and 2008.

\section{1- Season 2007}

The data illustrated in Fig. (1) showed that infestation of E. decipiens (Paoli) adults were stated at 15 days after sowing on $30^{\text {th }}$ September (21and 15 adult $/ 30$ leaves) on Hageen eshrak and Amira cucumber cultivars, respectively. It was increased sharply to reach its maximum ( 81 and 87 adult /30 leaves) at 22 days after sowing on $14^{\text {th }}$ October for Hageen eshrak and Amira cultivars respectively.

After that the insect population fluctuated then decreased gradually to reach a lower level (12 and 3 adult / 30 leaves) on $9^{\text {th }}$ December after 85 days from sowing for Hageen eshrak and Amira cultivars, respectively. Meanwhile, data indicated also that adult population of E. discipiens was obviously higher on young plants (3-6 weeks) than the older plants of the two cucumber cultivars. This result indicated that young fresh plants showed higher biological activities with turgid fully nourished cells than older cucumber plants and was more suitable for the reproduction of the insect pest. These results were in agreement with Hamdy (1992), Hamdy and Emam (1994) and Ebadah (2002).

The data illustrated in Fig. (2) showed that infestation of $A$. gossypii (Glover)adults plus immature stages were stated at 15 days after sowing on $30^{\text {th }}$ September (81and 51adult plus imm. /30 leaves) on Hageen eshrak and Amira cultivars, respectively. Then it increased sharply to reach its maximum (600 and 600 adult plus imm. / 30 leaves) at 43 days after sowing on $28^{\text {th }}$ October for Hageen eshrak and Amira cultivars, respectively. After that the insect population fluctuated and decreased slowly to reach lower values (126 and 225 adult plus imm. /30 leaves) in 85 days after sowing on $9^{\text {th }}$ December for Hageen eshrak and Amira cultivars, respectively. This result indicated also that young fresh cucumber plants harbored higher insect populations than the old one. These results were in agreement with ElSayed (1978), Dibble (1980), Nazato (1988), Steenis et al. (1995) and Hanafy (2004). 


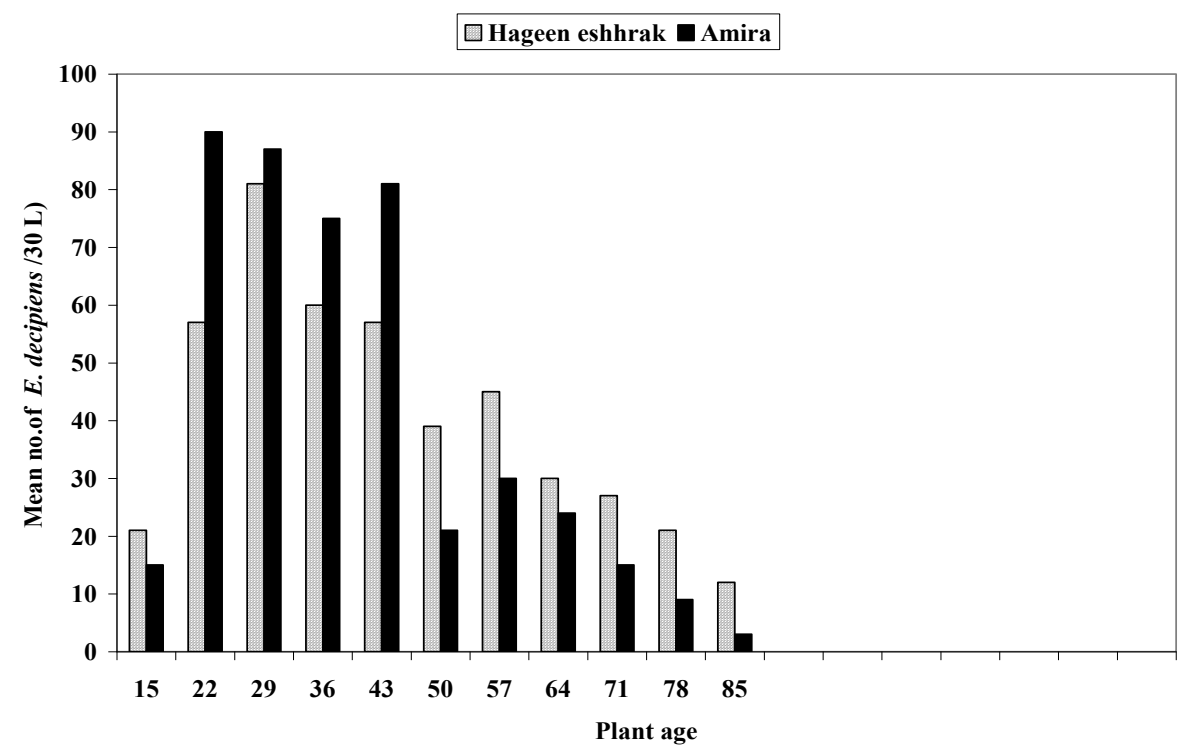

Fig. 1. Susceptibility of the two cucumber cultivars (Hageen eshrak and Amira) to infestation with E. decipiens during Nili plantation of 2007.

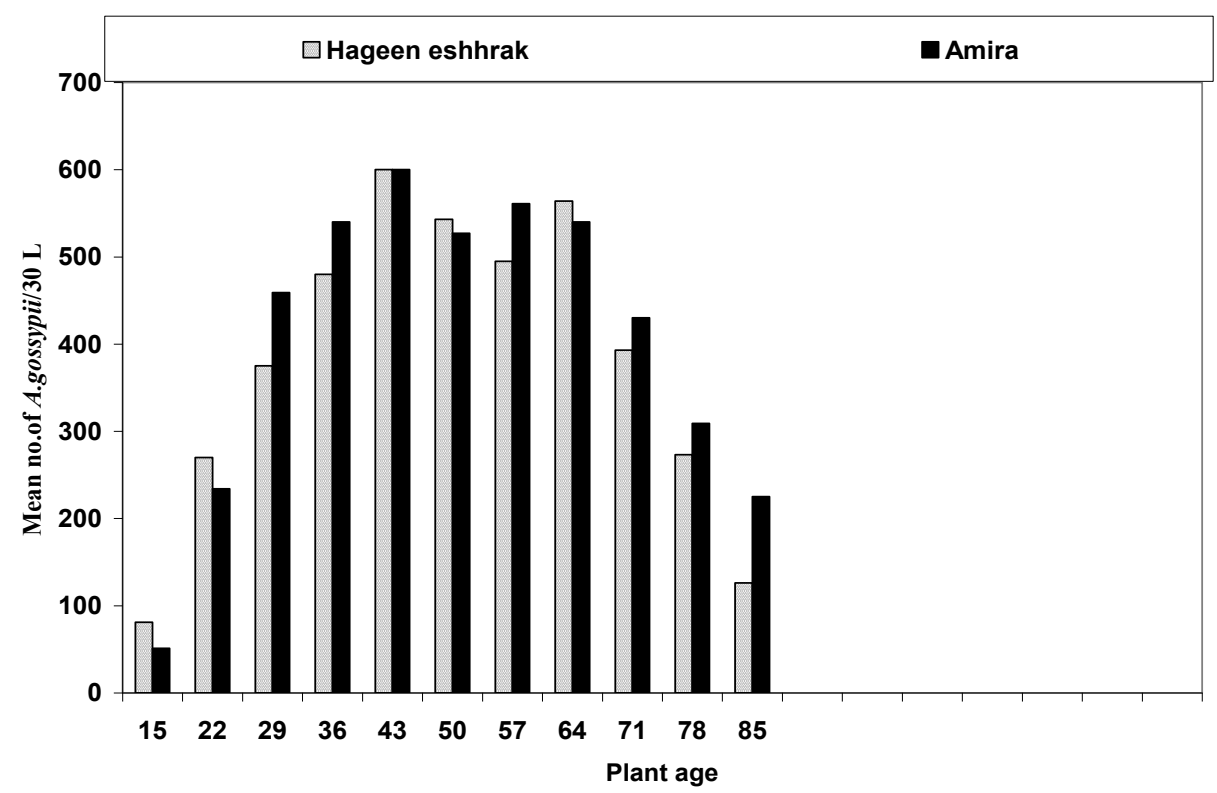

Fig. 2. Susceptibility of the two cucumber cultivars (Hageen eshrak and Amira) to infestation with A. gossypii during Nili plantation of 2007.

The data illustrated in Fig. (3) showed that leaves infestation with Bemisia tabaci adults plus immature stages population were appeared at 15 days after sowing on $30^{\text {th }}$ September (400 and 233 adult plus imm. /30 leaves) on Hageen eshrak and Amira cucumber cultivars, respectively, then it increased gradually to reach its maximum (2619 and 2952 adult plus imm./30 leaves) at 43 days after sowing on $28^{\text {th }}$ October for Hageen eshrak and Amira cultivars, respectively. 
After that the insect population dropped sharply then increased again to reach (1410 and 2040 adult plus imm. /30 leaves) at 57 days after sowing on $11^{\text {th }}$ November for Hageen eshrak and Amira cucumber cultivars, respectively.

After that the insect population decreased gradually to reach lower levels (384 and 285adult plus imm. $/ 30$ leaves) at 85 days after sowing on $9^{\text {th }}$ December for Hageen eshrak and Amira cucumber cultivars, respectively. Meanwhile, data revealed also that the young cucumber plants harbored higher B. tabaci populations than older plants, indicating that the young fresh plants were more suitable as a host for the white flies than older plants. These results were in agreement with El-Sirwy and ElHaidary (1984), Salem (1993), Dawood (1999) and Hanafy (2004).

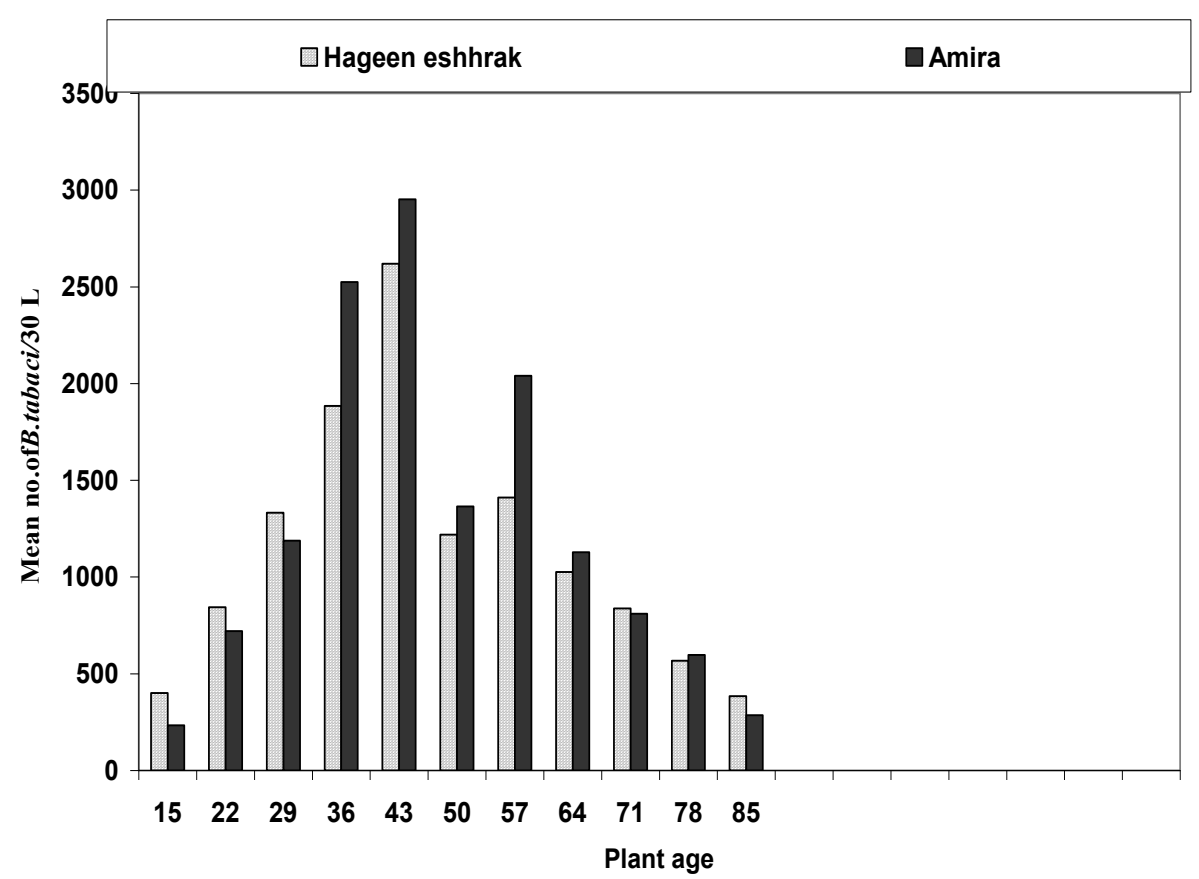

Fig. 3. Susceptibility of the two cucumber cultivars (Hageen eshrak and Amira) to infestation with $B$. tabaci adults plus immature stages during Nili plantation of 2007.

Data in Fig. (4) indicated also that the two cucumber cultivars harbored higher B. tabaci than A. gossypii populations in comparison to E. decipiens population during Nili plantation of 2007 years. 

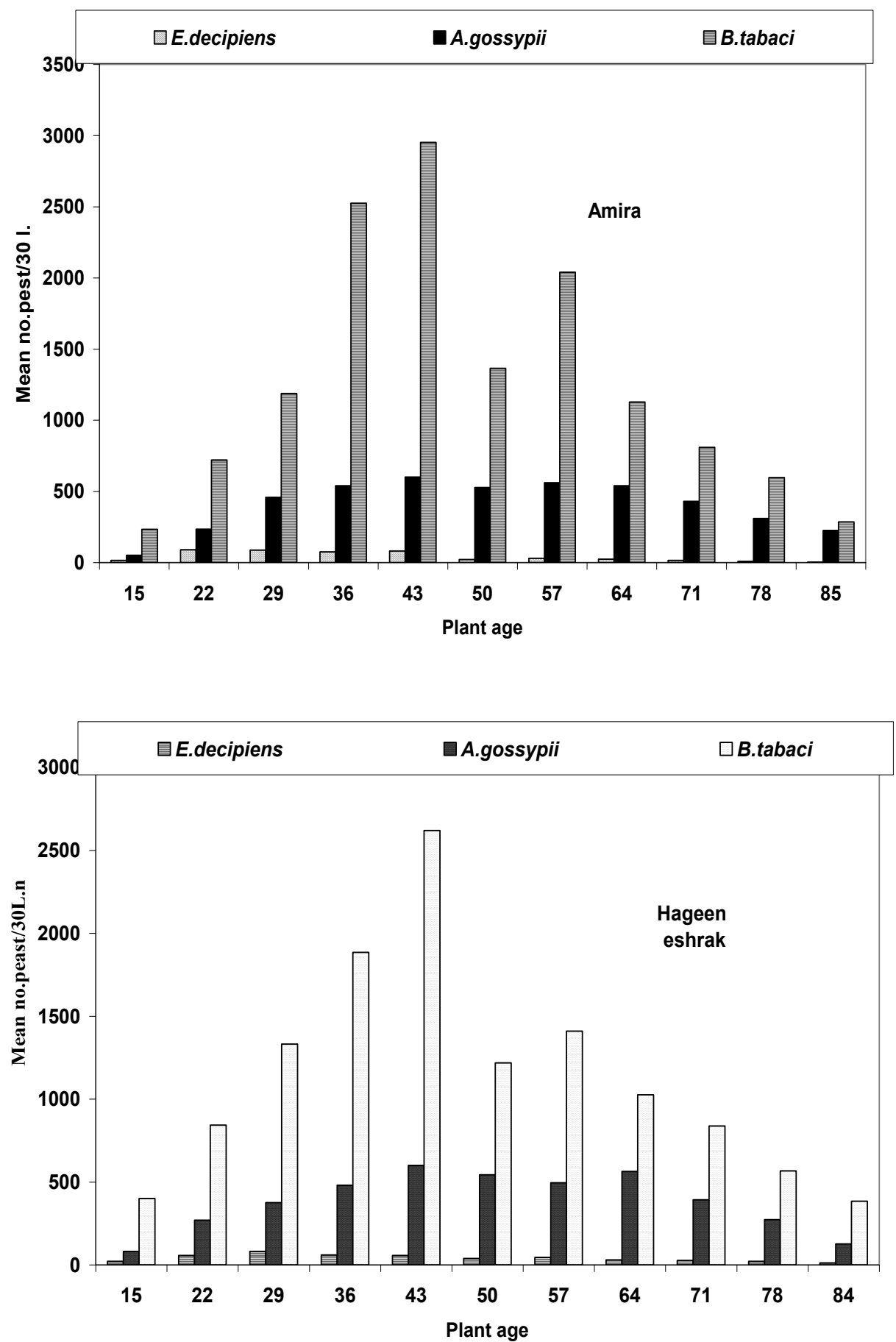

Fig. 4. Susceptibility of the two cucumber cultivars (Hageen eshrak and Amira) to infestation with some pests during Nili plantation of 2007.

The simple correlation " $r$ " indicated significant positive correlation between the age of cucumber plants and the populations of E. decipiens, A. gossypii and B. tabaci on cucumber cultivars (Hageen eshrak, Amira), $(r=-0.658 \& 0.605),(r=0.502 \&$ $0.547)$ and $(r=0.673 \& 0.686)$, respectively. The real effect of this factor which 
appears from the partial regression values on the Aphis gossypii population revealed insignificant positive effect (b.reg. $=2.77 \& 1.66$ ) for cucumber cultivars (Hageen eshrak, Amira), while on the $E$. decipiens and B. tabaci population revealed significant positive effect (b.reg. $=3.95 \& 2.274$ ) and (b.reg. $=2.95 \& 8.149$ ) for the two cultivars respectively, during the season of 2007 .

The results indicated significant positive correlation between the populations of insects and mean daily maximum and minimum temperatures with the two cultivars (Hageen eshrak, Amira), ( $r=0.950 \& 0.951)$ and $(r=0.950 \& 0.951)$, respectively, during 2007 season. Contrarily insignificant positive correlation was found between the insect populations and daily relative humidity with the two cucumber cultivars (Hageen eshrak and Amira), ( $r=0.437 \& 0.437)$, respectively, during the season of 2007 , as shown in (Tables 1\&2). The partial regression analysis for the effect of weather factors on the pest populations revealed that means of daily maximum and minimum temperatures had significant positive effect (b.reg. $=4.60 \& 5.44$ ) and (b.reg. $=$ 14.10\& 1.104) on cucumber cultivar (Hageen eshrak, Amira), respectively, during the season of 2007, as shown in Tables (1\&2). While, the means of daily relative humidities had insignificant negative effect (b.reg $=-9.09$ ) and (b.reg $=-1.41$ ) for the two cucumber cultivars (Hageen eshrak and Amira), respectively, during this season. These results are in agreement with Attia and Hamaky (1987).

Table 1. Effect of plant age and weather factors on the population fluctuations of some pests infesting cucumber cultivar (Hageen eshrak) during Nili plantation of 2007 in Qualubia Governorate.

\begin{tabular}{|c|c|c|c|c|c|c|c|c|c|c|}
\hline \multirow{2}{*}{\multicolumn{2}{|c|}{ Factors }} & \multicolumn{3}{|c|}{$\begin{array}{l}\text { Simple correlation and } \\
\text { regression values }\end{array}$} & \multicolumn{3}{|c|}{ Partial regression values } & \multicolumn{2}{|c|}{$\begin{array}{l}\text { Analysis of } \\
\text { variance }\end{array}$} & \multirow{2}{*}{$\begin{array}{c}\text { E.V. } \\
\%\end{array}$} \\
\hline & & $r$ & $b$ & S.E. & b. reg. & S.E. & $P$ & $\mathrm{~F}$ & $P$ & \\
\hline \multirow{3}{*}{ pests } & $\begin{array}{l}\text { Empousca } \\
\text { discipiens }\end{array}$ & 0.658 & $\begin{array}{c}- \\
2.658\end{array}$ & $\begin{array}{c}5.13 \\
3 \\
\end{array}$ & 3.95 & 0.137 & 0.03 & \multirow{6}{*}{19.02} & \multirow{6}{*}{0.01} & \multirow{6}{*}{92.7} \\
\hline & $\begin{array}{c}\text { Aphis } \\
\text { gossypii }\end{array}$ & 0.502 & 3.651 & $\begin{array}{c}3.92 \\
9 \\
\end{array}$ & 2.77 & 0.207 & 0.09 & & & \\
\hline & $\begin{array}{c}\text { Bemisia } \\
\text { tabaci }\end{array}$ & 0.673 & 7.649 & $\begin{array}{c}2.77 \\
7 \\
\end{array}$ & 2.950 & 0.219 & 0.05 & & & \\
\hline \multirow{3}{*}{$\begin{array}{l}\text { weather } \\
\text { factors }\end{array}$} & $\begin{array}{l}\text { Daily } \\
\text { mean } \\
\text { max. } \\
\text { temp. }\end{array}$ & 0.950 & 2.679 & 4.30 & 4.60 & 0.394 & 0.05 & & & \\
\hline & $\begin{array}{c}\text { Daily } \\
\text { mean min. } \\
\text { temp. }\end{array}$ & 0.951 & 5.31 & 1.41 & 14.10 & 0.624 & 0.03 & & & \\
\hline & $\begin{array}{c}\text { Daily } \\
\text { mean R.H. }\end{array}$ & 0.437 & -1.76 & $\begin{array}{c}0.90 \\
9\end{array}$ & -9.09 & 0.949 & 0.1 & & & \\
\hline
\end{tabular}

r: Simple correlation value.

b: Simple regression coefficient value. b. reg.: Partial regression coefficient value.

E.v.: Explained variance. 
The obtained results revealed that the combined effect of the tested plant age and weather factors was significant on the insects population where the calculated " $f$ " values were 19.02 and 18.79 for the two cucumber cultivars (Hageen eshrak and Amira), respectively, during Nili plantation 2007.

The analysis of the variance revealed that the weather factors and the plant age are responsible for about 92.7 and $84.5 \%$ of the variability in the populations of the observed pests on the two cucumber cultivars during Nili plantation 2007.

Table 2. Effect of plant age and weather factors on the population fluctuations of some pests infesting cucumber cultivar (Amira) during Nili plantation of 2007 in Qualubia Governorate.

\begin{tabular}{|c|c|c|c|c|c|c|c|c|c|c|}
\hline \multirow{2}{*}{\multicolumn{2}{|c|}{ Factors }} & \multicolumn{3}{|c|}{$\begin{array}{l}\text { Simple correlation and } \\
\text { regression values }\end{array}$} & \multicolumn{3}{|c|}{ Partial regression values } & \multicolumn{2}{|c|}{$\begin{array}{c}\text { Analysis of } \\
\text { variance }\end{array}$} & \multirow{2}{*}{$\begin{array}{c}\text { E.V. } \\
\%\end{array}$} \\
\hline & & $r$ & b & S.E. & b. reg. & S.E. & $P$ & $\mathrm{~F}$ & $\mathrm{P}$ & \\
\hline \multirow{3}{*}{ pests } & $\begin{array}{l}\text { Empousca } \\
\text { discipiens }\end{array}$ & 0.605 & 1.520 & 0.82 & 2.274 & 0.123 & 0.01 & \multirow{6}{*}{18.79} & \multirow{6}{*}{0.05} & \multirow{6}{*}{84.5} \\
\hline & $\begin{array}{c}\text { Aphis } \\
\text { gossypii }\end{array}$ & 0.547 & 2.169 & 0.23 & 1.66 & 0.179 & 0.09 & & & \\
\hline & $\begin{array}{c}\text { Bemisia } \\
\text { tabaci }\end{array}$ & 0.686 & 2.096 & 0.48 & 8.149 & 0.188 & 0.05 & & & \\
\hline \multirow{3}{*}{$\begin{array}{l}\text { weather } \\
\text { factors }\end{array}$} & $\begin{array}{c}\text { Daily } \\
\text { mean } \\
\text { max. } \\
\text { temp. }\end{array}$ & 0.950 & 3.085 & 2.209 & 5.44 & 0.370 & 0.04 & & & \\
\hline & $\begin{array}{c}\text { Daily } \\
\text { mean min. } \\
\text { temp. }\end{array}$ & 0.951 & 4.148 & 2.108 & 1.104 & 0.499 & 0.06 & & & \\
\hline & $\begin{array}{c}\text { Daily } \\
\text { mean R.H. }\end{array}$ & 0.437 & 3.354 & 0.226 & -1.41 & 0.526 & 0.1 & & & \\
\hline
\end{tabular}

r: Simple correlation value.

b: Simple regression coefficient value. b. reg.: Partial regression coefficient value.

E.v.: Explained variance.

\section{Season 2008}

The data illustrated in Fig. (5) showed that plants infestation by Empousca discipiens during 2008 season was observed in 17 days after sowing on $22^{\text {th }}$ September (30and 21 adult /30 leaves) on Hageen eshrak and Amira cucumber cultivars, respectively. Then the insect population increased rapidly to reach its maximum (90 and 96 adult $/ 30$ leaves) at 38 days after sowing on $13^{\text {th }}$ October on Hageen eshrak and Amira cultivars, respectively. After that the population decreased gradually to reach ( 9 and 6 adult $/ 30$ leaves) after 94 days from sowing on $8^{\text {th }}$ December on Hageen eshrak and Amira cultivars respectively. Meanwhile, data indicated also that the adult population size of this insect species was higher for young cucumber plants (3-8 weeks) than for older plants (8-12 weeks). This result indicates 
that young fresh plants having highest biological activities with turgid fully nourished cells are more suitable for the reproduction of the insect species than older one. These results are in agreement with Hamdy (1992), Hamdy and Emam (1994) and Ebadah (2002).

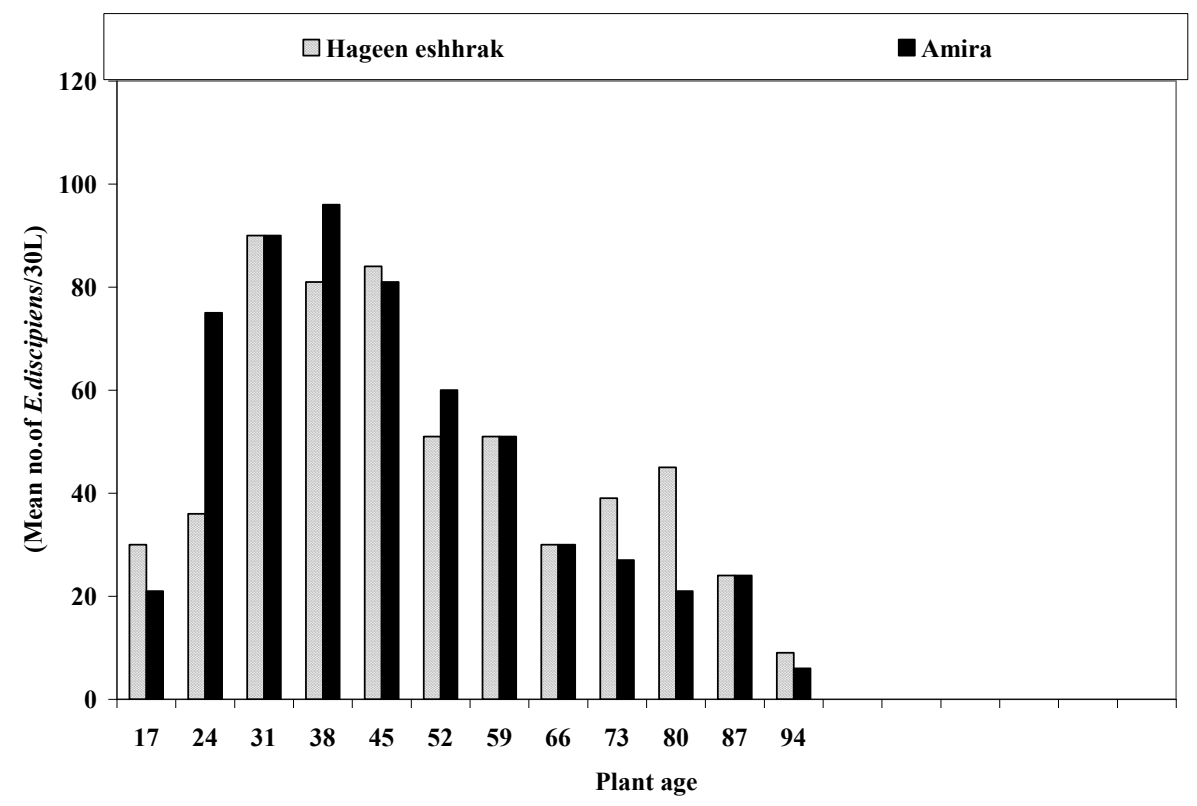

Fig. 5. Susceptibility of the two cucumber cultivars (Hageen eshrak and Amira) to infestation with E. decipiens during Nili plantation of 2008.

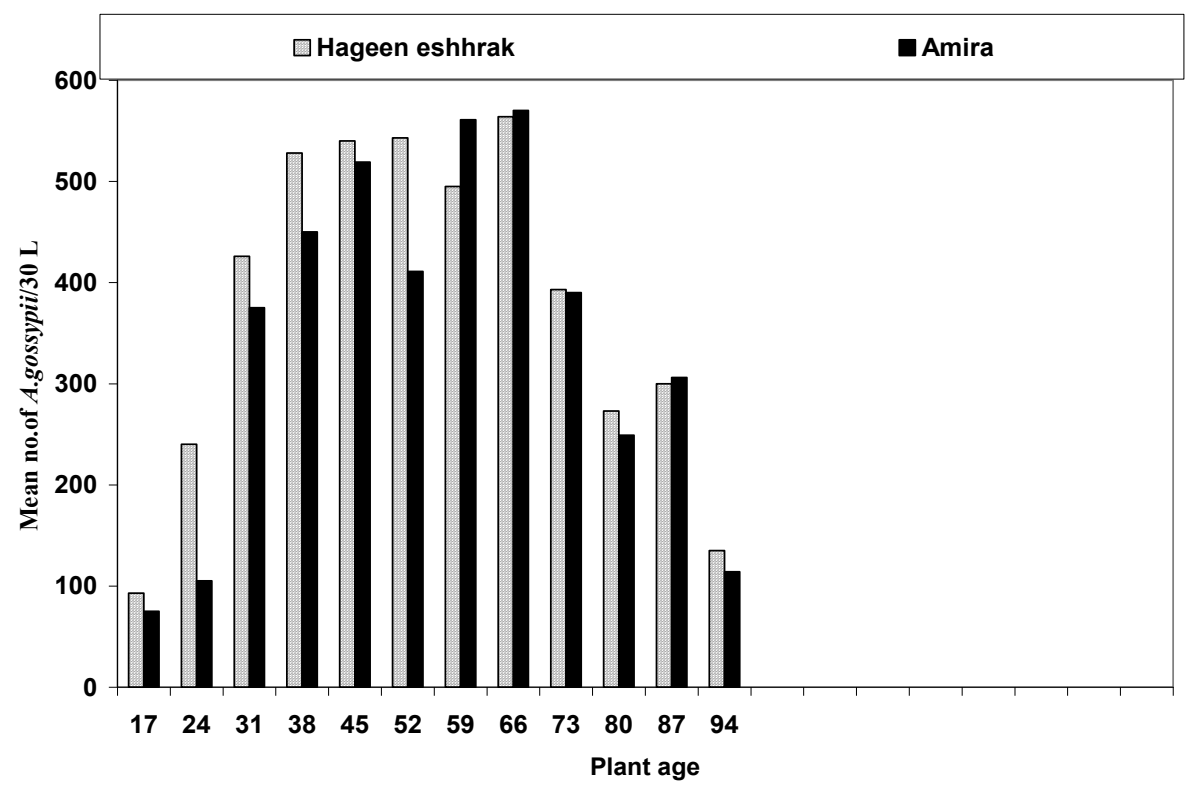

Fig. 6. Susceptibility of the two cucumber cultivars (Hageen eshrak and Amira) to infestation with A.gossypii during Nili plantation of 2008. 
The data illustrated in Fig. (6) showed that the plants infestation by $A$. gossypii population during 2008 was recorded at 17 days after sowing on $22^{\text {th }}$ September (93and 75adult plus imm. stages /30 leaves) on Hageen eshrak and Amira cultivars respectively. Then the insect population increased to reach its maximum (564 and 570 adult and imm. /30 leaves) at 66 days after sowing on $10^{\text {th }}$ November on Hageen eshrak and Amira cultivars respectively. After that the insect population dropped sharply to reach (135 and 114 adult and imm. /30 leaves) at 94 days after sowing on $8^{\text {th }}$ December on Hageen eshrak and Amira cultivars, respectively. Meanwhile, data indicated also that the population of adults and immature stages of $A$. gossypii on the cucumber plants was higher on young fresh plants than on older one. These results were in agreement with El-Sayed (1978), Dibble (1980), Nazato (1988), Steenis et al. (1995) and Hanafy (2004).

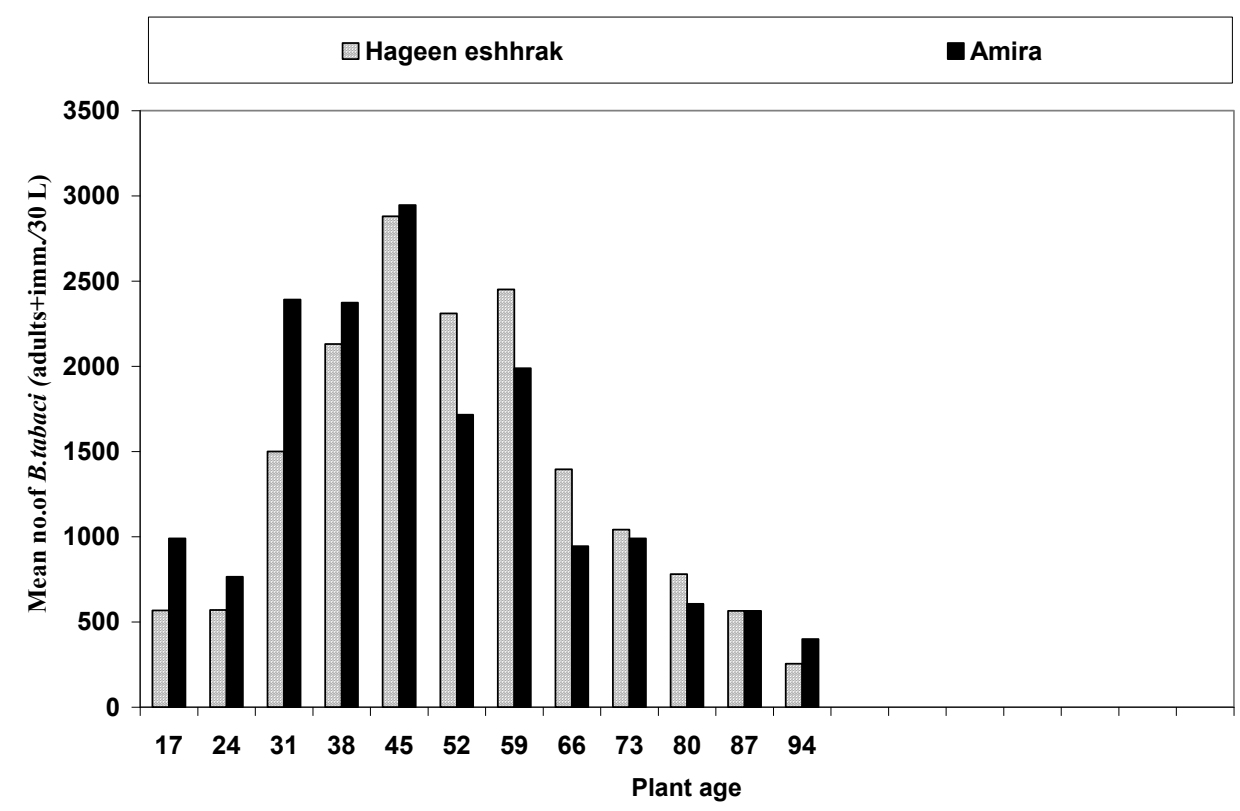

Fig. 7. Susceptibility of the two cucumber cultivars (Hageen eshrak and Amira) to infestation with B. tabaci adults plus immature stages during Nili plantation of 2008.

The data illustrated in Fig. (7) indicated that plants infestation with Bemisia tabaci population during 2008 was recorded in 17 days after sowing on $22^{\text {th }}$ September (567 and 990 adult and imm. /30 leaves) on Hageen eshrak and Amira cultivars respectively. Then the insect population increased rapidly to reach its maximum (2880 and 2946 adult and imm./30 leaves) in45 days after sowing on $20^{\text {th }}$ October on Hageen eshrak and Amira cultivars, respectively. After that the total population of this species fluctuated to reach (2451 and 1989 adult and imm. /30 
leaves) in 59 days after sowing on $3^{\text {th }}$ November on Hageen eshrak and Amira cultivars respectively. Then it decreased gradually to reach a lower level (255 and 399 adult and imm. / 30 leaves) in 94 days after sowing on $8^{\text {th }}$ December on Hageen eshrak and Amira cultivars respectively. Meanwhile, results indicated also that young fresh cucumber plants harbored higher insect population than older plants of the two cucumber cultivars. These results were in agreement with El-Sirwy and El-Haidary (1984), Salem (1993), Dawood (1999) and Hanafy (2004).
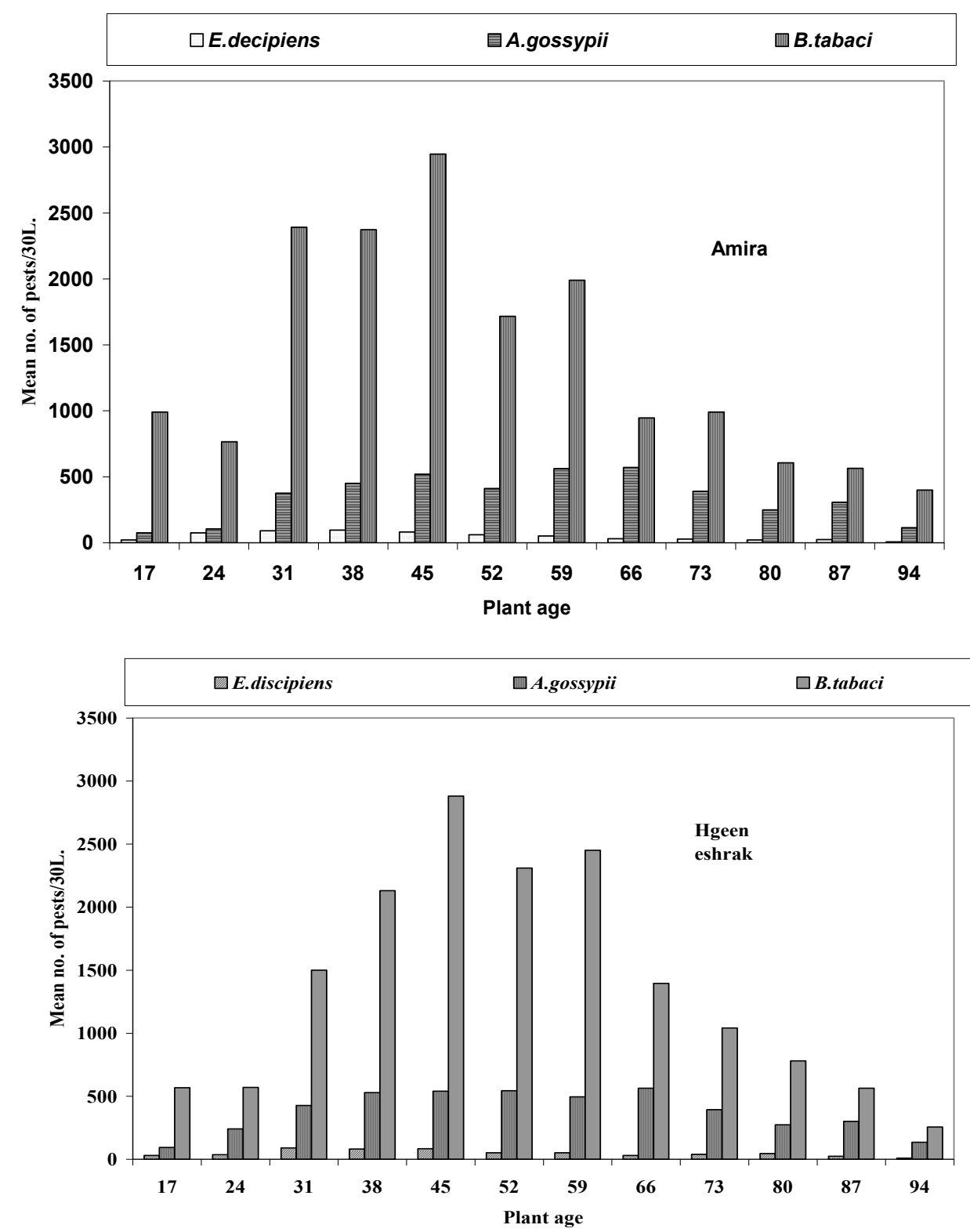

Fig. 8. Susceptibility of the two cucumber cultivars (Hageen eshrak and Amira) to infestation with some pests during Nili plantation of 2008. 
Data in Fig. (8) revealed that the population size of the various insects on the two cultivars of cucumber during Nili plantation of 2008 years, could be arranged in descending order as follows $B$. tabaci population then A. gossypii and E. decipiens population indicating that $B$. tabaci had shown the highest population size on cucumber plants.

The simple correlation " $r$ " indicated significant positive correlation between the plant age and the populations of E. decipiens, A.gossypii and B. tabaci on cucumber cultivars (Hageen eshrak and Amira), $(r=0.508 \& 0.656),(r=0.55 \& 0.97)$ and $(r=$ $0.87 \& 0.74$ ) respectively, during the season of 2008 (Tables 3\& 4). The real effect of this factor which appears from the partial regression values on the Aphis gossypii and B. tabaci population revealed insignificant positive effect (b.reg. $=0.988 \& 1.973$ ) and (b.reg. $=1.66 \& 7.728$ ) for cucumber cultivars (Hageen eshrak, Amira), while on $E$. decipiens population revealed significant positive effect (b.reg. $=1.955 \& 2.942)$ for two cucumber cultivars, respectively, during the Nili plantation of 2008.

The results indicated significant positive correlation between the populations of the pests and the mean of daily maximum and minimum temperatures with cucumber cultivars (Hageen eshrak, Amira), ( $r=0.981 \& 0.881)$ and $(r=0.931 \& 0.971)$, respectively, during the season of 2008.

Contrarly insignificant negative correlation was found between the daily relative humidity and the populations of the pests on cucumber cultivars (Hageen eshrak, Amira), ( $r=-0.17 \&-0.17)$, respectively, during 2008 year. The partial regression analysis for the effect of weather factors on the pest populations revealed that means of daily maximum and minimum temperatures had significant positive effect (b.reg. = $3.2 \& 3.206)$ and (b.reg. $=2.63 \& 1.654$ ) on two cucumber cultivars, respectively, during the season of 2008 , as given in Tables (3\& 4). While, the means of daily relative humidities had highly significant negative effect (b.reg $=-3.249 \&-1.161$ ) on cucumber cultivars (Hageen eshrak, Amira), respectively, during this season.

The obtained results revealed that the combined effect of the tested plant age and weather factors was highly significant on the insects population where the calculated "f" values were 25.72 and 26.69 for the two cucumber cultivars (Hageen eshrak and Amira), respectively, during Nili plantation 2008.

The analysis of variance revealed that the weather factors and the plant age are responsible for about 98.6 and $94.2 \%$ of the variability in the populations of the observed pests on the two cucumber cultivars during Nili plantation in 2008. 
Table 3. Effect of plant age and weather factors on the population fluctuation of some pests infesting cucumber cultivar (Hageen eshrak) during Nili 2008 inQualubia Governorate.

\begin{tabular}{|c|c|c|c|c|c|c|c|c|c|c|}
\hline & \multirow{2}{*}{ Factors } & \multicolumn{3}{|c|}{$\begin{array}{l}\text { Simple correlation and } \\
\text { regression values }\end{array}$} & \multicolumn{3}{|c|}{ Partial regression values } & \multicolumn{2}{|c|}{$\begin{array}{c}\text { Analysis of } \\
\text { variance }\end{array}$} & \multirow{2}{*}{$\begin{array}{c}\text { E.V. } \\
\%\end{array}$} \\
\hline & & $r$ & b & S.E. & b. reg. & S.E. & P & r & $P$ & \\
\hline \multirow{3}{*}{ pests } & $\begin{array}{l}\text { Empousca } \\
\text { discipiens }\end{array}$ & 0.750 & 0.193 & 0.783 & 1.955 & 0.138 & 0.03 & \multirow{6}{*}{25.72} & \multirow{6}{*}{0.001} & \multirow{6}{*}{98.6} \\
\hline & Aphis gossypii & 0.55 & 0.148 & 0.149 & 0.988 & 0.136 & 0.34 & & & \\
\hline & Bemisia tabaci & 0.87 & 0.455 & 0.322 & 1.66 & 0.209 & 0.18 & & & \\
\hline \multirow{3}{*}{$\begin{array}{l}\text { weath } \\
\text { er } \\
\text { factor } \\
\mathrm{s}\end{array}$} & $\begin{array}{l}\text { Daily mean } \\
\text { max. temp. }\end{array}$ & 0.981 & 1.67 & 1.53 & 3.2 & 1.13 & 0.016 & & & \\
\hline & $\begin{array}{l}\text { Daily mean } \\
\text { min. temp. }\end{array}$ & 0.931 & 6.51 & 1.43 & 2.63 & $\begin{array}{c}- \\
0.526\end{array}$ & 0.026 & & & \\
\hline & $\begin{array}{l}\text { Daily mean } \\
\text { R.H. }\end{array}$ & $\begin{array}{l}-0 . \\
17\end{array}$ & $\begin{array}{c}- \\
1.282\end{array}$ & 3.66 & -3.249 & 0.129 & 0.006 & & & \\
\hline
\end{tabular}

r: Simple correlation value.

b: Simple regression coefficient value. b. reg.: Partial regression coefficient value. E.v.: Explained variance.

Table 4. Effect of plant age and weather factors on the population fluctuation of some pests infesting cucumber cultiva (Amira) during Nili 2008 inQualubia Governorate

\begin{tabular}{|c|c|c|c|c|c|c|c|c|c|c|}
\hline & \multirow{2}{*}{ Factors } & \multicolumn{3}{|c|}{$\begin{array}{l}\text { Simple correlation and } \\
\text { regression values }\end{array}$} & \multicolumn{3}{|c|}{ Partial regression values } & \multicolumn{2}{|c|}{$\begin{array}{l}\text { Analysis of } \\
\text { variance }\end{array}$} & \multirow{2}{*}{$\begin{array}{c}\text { E.V. } \\
\%\end{array}$} \\
\hline & & $r$ & $b$ & S.E. & b. reg. & S.E. & $P$ & $\mathrm{~F}$ & $P$ & \\
\hline \multirow{3}{*}{ pests } & $\begin{array}{l}\text { Empousca } \\
\text { discipiens }\end{array}$ & 0.656 & 0.766 & 0.122 & 2.942 & 0.150 & 0.01 & \multirow{6}{*}{26.69} & \multirow{6}{*}{0.003} & \multirow{6}{*}{94.2} \\
\hline & Aphis gossypii & 0.97 & 0.139 & 0.239 & 1.973 & 0.166 & 0.08 & & & \\
\hline & Bemisia tabaci & 0.74 & 0.220 & 0.506 & 7.728 & 0.167 & 0.06 & & & \\
\hline \multirow{3}{*}{$\begin{array}{l}\text { weath } \\
\text { er } \\
\text { factor } \\
\text { s }\end{array}$} & $\begin{array}{l}\text { Daily mean } \\
\text { max. temp. }\end{array}$ & 0.881 & 1.465 & 7.83 & 3.206 & 1.101 & 0.04 & & & \\
\hline & $\begin{array}{l}\text { Daily mean } \\
\text { min. temp. }\end{array}$ & 0.971 & 5.066 & 4.73 & 1.654 & 0.611 & 0.03 & & & \\
\hline & $\begin{array}{c}\text { Daily mean } \\
\text { R.H. }\end{array}$ & $\begin{array}{l}-0 \\
17\end{array}$ & $\begin{array}{c}- \\
1.138\end{array}$ & 1.17 & -1.161 & 1.559 & 0.01 & & & \\
\hline
\end{tabular}

r: Simple correlation value.

b: Simple regression coefficient value. b. reg.: Partial regression coefficient value.

E.v.: Explained variance.

\section{Susceptibilities of the two cucumber cultivars to the three insects in two}

The mean values of the insect populations on the two cucumber cultivars during the Nili plantation of 2007 and 2008 year given in fig. (9) revealed clearly no significant differences in the susceptibilities of the two cucumber cultivars (Hageen eshrak and Amira) to infestation with the various pests of cucumber plants during 2007 and 2008 seasons. 

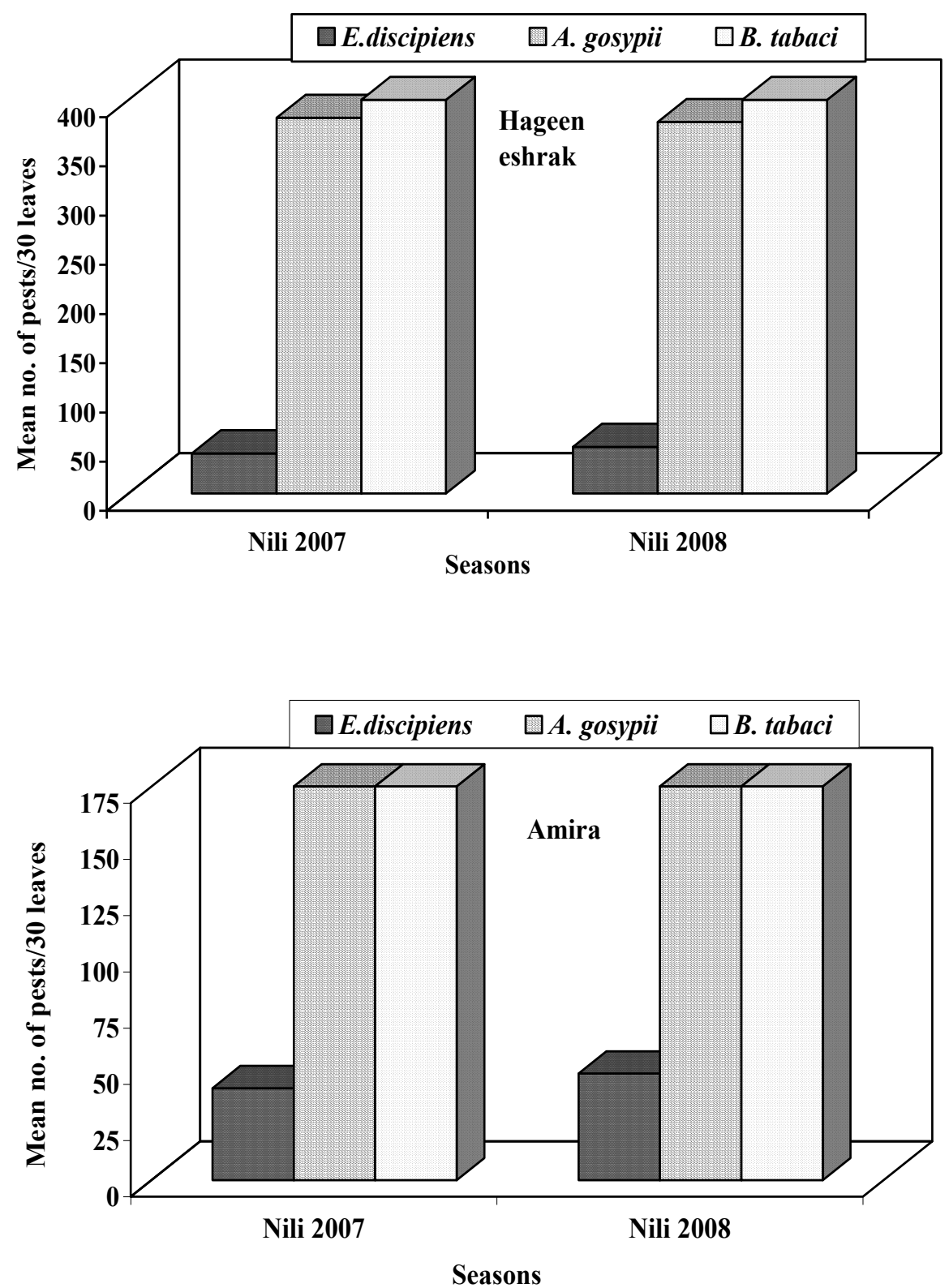

Fig. 11. Susceptibility of two cucumber cultivars to duringNili pests infestation 2007,2008 seasons at Qalyubiya Governorate. 


\section{REFERENCES}

1. Attia, A. A., and M. A. El Hamaky. 1987. The biology of the cotton aphid, Aphis gossypii Glover, in Egypt (Homoptera: Aphididae).Bull. Soc. Entomo. Egypt, 65: 359-371.

2. Bock, K. R., E. j. Guthrie and R. D. Woods. 1974. Purification of maize streak virus and its relationship to viruses associated with streak diseases of sugarcane and Panicam maximum. Annals of Appl. Bio. 77:289-296.

3. Dawood, M. Z. 1999. Susceptibility of certain commonly cultivated Squash and cucumber cultivars to Bemisia tabaci (Genn.) (Homoptera:Alyrodidae ) In Benisuef Governorate. Egypt J. Agric. Res., 77 (3): 1075-1079.

4. Dibble, J. E. 1980. Insect pest management on cucurbits.California University, San Joaquin Valley Agricultural Research and Extension Center, USA. Abst. Rev. Appl. Entomo., 1980: 1488.

5. Ebadah, I. M. A. 2002. Population fluctuations and diurnal activity of the leafhopper, Empoasca decipiens on some summer crops in Kalubia Governorate, Egypt. Bull. Fac. Agric., Cairo Univ. 53(4): 653-670.

6. El Sayed, M. Z. D. 1978. Studies on Hemiperous insects infesting cucurbitaceous vegetable plants and their role in transmitting plant diseases. Ph. D. thesis, Fac. Agric., Cairo Univ. 219 PP.

7. El- Serwiy, S. and S. A. El-Haidari. 1984. population density of the whitefly Bemisia tabaci (Genn.) Homoptera: Alyrodidae on fall cucumber in Iraq. J. Agric. Water Resources Res., 3:2. Abst. Rev. Appl. Entomo., 3476.

8. Gameel, O. I. (1973): Field evaluation of insecticides for jassid, Empoasca lybica De Berg and whitefly, Bemisia tabaci (Genn.) control on cotton. Bull. Entomo. Soc. Egypt, Econo. Ser., 7: 113-122.

9. Hamdy, M. K. 1992. Some ecological aspects on the leafhopper, Empoasca decipiens (Paoli) (Homoptera: Cicadellidae) attacking summer vegetable plants in Sharkia Governorate Annals-of-Agric.Sci. Cairo. 37(2): 613-620.

10. Hamdy, M. K and A. K. Emam. 1994. Diurnal activity of the leafhopper, Empoasca decipiens (Paoli) (Homoptera: Cicadellidae) on summer vegetable plants in Egypt. Annals-of-Agric. Sci. Cairo. 39(1): 425-430.

11. Hanafy, A. R. I. 2004. Studies on the most important cucumber pests in the open field and suitable control programs. Ph. D. thesis, Fac. of. Agric. Moshtohor, Benha Branch- Zagazig Univ.279PP, Egypt.

12. Kasperovich, E. 2002. Application of baciturine in Aphis gossypii and Tetranychus urticae number limitation in the protected ground. Scientific Conference- 
dedicated-to-the-90th-anniversary-of-the-birth-of-the-Corresponding-Member-ofthe-AS-RB-AL- Samersov-Minsk-Prilukii, 177-180.

13. Lenteren Van, J. C. and L. P. J.J. Noldus. 1984. Whitefly- plant relationship: Behavioural and ecological aspect. In (whiteflies: their Bionomcs, pest status and management.) (Gerling, D. Ed.) Published intercept Ltd., 348.

14. Nazato, K. 1988. Population growth of the melon aphid, Aphis gossypii Glov.(Homoptera: Aphididae) during a year in the warmer region of Japan. Research Reports of the Kochi Unvi., Agric. Sci., 37:121-129.

15. Perkins, H. H. 1983. Identification and processing of honeydew contaminated cotton. Textile Research J. pp. 508-512.

16. Perkins, H. H. 1987. Sticky cotton. Proceedings of the Western cotton production conference pp. 53-55.

17. Salem, M. 1993. Distribution pattern of infestation and control of whitefly, Bemisia tabaci (Genn.) on cucumber plants in the greenhouse. Annal Agric. Sci. Ain shams Univ., Cairo, 38 (2):783-793.

18. Steenis Van. M. J., K. A. M. H. El- Khawass and M. J. Van steenis. 1995. Life history of Aphis gossypii on cucumber influence of temperature, host plant and parasitism. Entomo. experimentalist applicata 76, (2), 121-131. 


\section{ديناميكية التعداد لبعض الآفات التى تصيب زراعات الخيار النيلى و علاقتها ببعض العوامل البيئية}

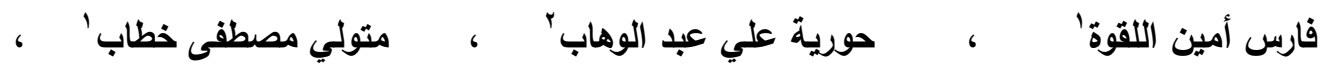

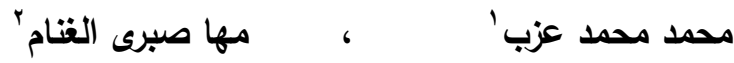

$$
\text { r ا ـ كلية الزراعة بشتنه - جامعة بنها. }
$$

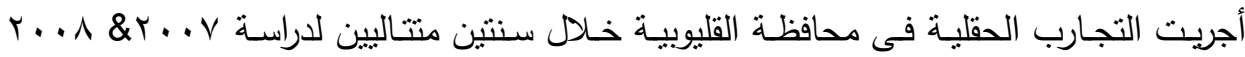
لديناميكية التعداد لبعض الأفات التى تصيب زراعات الخيار فى العروة النيلى و هى من القطن Aphis - Bemissia tabaci ( Genn) الذبابة البيضاء - Bosyii Glover Empoasca decipiens (Paoli)

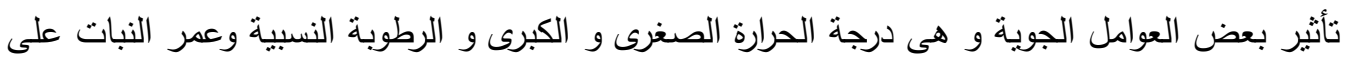
التغير لتعداد الأفات المذكورة. وأظهرت النتائج أنـه لا يوجد فروق معنوية فى حساسية صنفى الخيار هجين أثنراق و أميرة و درجة

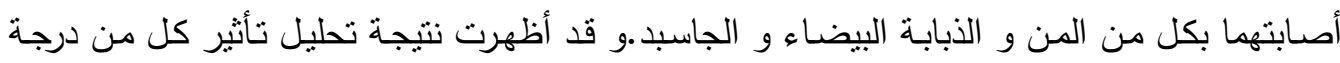

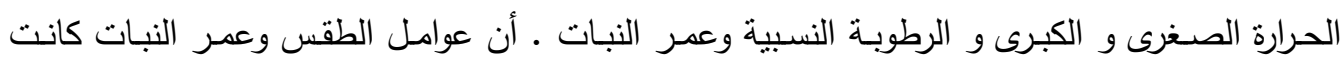

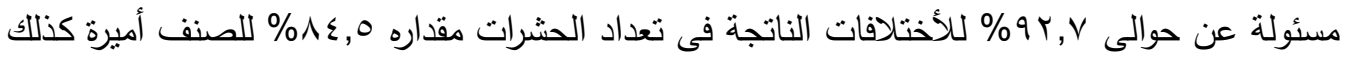

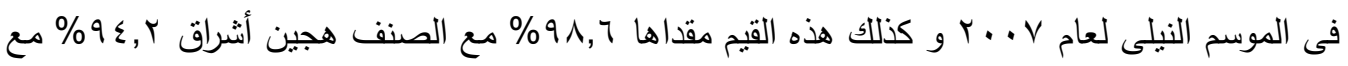

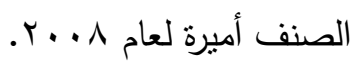

